УДК 378:796.071.4

DOI:

Ольга Романчук, кандидат філологічних наук, доцент, докторант кафедри загальної педагогіки та дошкільної освіти Дрогобииького державного педагогічного університету імені Івана Франка Мирослава Данилевич, кандидат наук з фізичного виховання та спорту, доцент кафедри фітнесу і рекреаџіi Львівського державного університету фізичної культури імені Івана Боберського

\title{
ПОНЯТІЙНИЙ АПАРАТ І ТЕРМІНОЛОГІЯ СИСТЕМИ ПІДГОТОВКИ ФАХІВЦІВ 3 ФІЗИЧНОГО ВИХОВАННЯ ТА СПОРТУ
}

У статті охарактеризовано базовий понятійний апарат і термінологія системи професійноі підготовки майбутніх фахівців з фізичного виховання та спорту. Акцентовано увагу на тому, що професійна підготовка є системою навчання або процесом отримання майбутнім фахівцем спеціальних знань, вмінь та навичок, особистісно-професійних якостей, щчо забезпечують можливість успішної роботи з певної професії. Уточнено сутність понять “формування професійної компетентності майбутніх фахівців з фізичного виховання та спорту у закладах вищої освіти" та “майбутні фахівці з фізичного виховання та спорту”.

Ключові слова: термін; поняття; професійна підготовка; майбутній фахівець; фізичне виховання і спорт. Puc. 1. Лim. 15.

Olha Romanchuk, Ph.D.(Philology), Associate Professor, Doctoral Student of the General Pedagogy and Preschool Education Department Drohobych Ivan Franko State Pedagogical University Myroslava Danylevych, Ph.D.(Physical Education and Sports), Associate Professor of the Fitness and Recreation Department, Lviv Ivan Boberskiy State University of Physical Culture

\section{CONCEPS AND TERMINOLOGY OF SYSTEM OF TRAINING OF SPECIALISTS IN PHYSICAL EDUCATION AND SPORTS}

The article describes the basic concepts and terminology of professional training system of future specialists in physical education and sports. The purpose of the paper is to study and analyze the key concepts of the professional training system of future specialists in physical education and sports. Achieving the purpose involves solving the following tasks: to analyze scientific and methodological literature on the research topic; to define the key concepts of the system of professional training of future specialists in physical education and sports; to select and describe the basic terms of professional training system of future specialists in physical education and sports. The emphasis is placed upon the fact that professional training is a system of training or the process of obtaining special knowledge, skills and abilities, personal and professional qualities that provide the opportunity for successful activities in a particular profession. The essence of the concepts "the formation of professional competence of future specialists in physical education and sports in higher education institutions" and "future specialists in physical education and sports" is specified.

Formation of professional competence of future specialists in physical education and sport in higher educational institutions is considered as a process of mastering professional knowledge, skills and abilities, practical experience, as well as professionally significant qualities sufficient for their individual creative contribution to the profession, stimulation the interest to the results of their activities, connected with the use of physical exercises, natural and hygienic factors during the free time for recovery, strengthen and maintaining the health. Future specialists in physical education and sport are considered as students of higher educational institutions, who have their own capacities and abilities, aim to obtain qualification during a certain period of studies and educational level, which will enable them to teach other people the main motives for achieving physical perfection.

Keywords: a term; a concept; professional training; future specialists; physical education and sports.

П остановка проблеми. Модернізація сучасної вищої фізкультурної освіти, в основі якої лежить гуманізація i гуманітаризація навчально-виховного процесу, визначає нові орієнтири іiї розвитку. Головною метою $\epsilon$ виховання всебічно розвинутої особистості фахівця з фізичного виховання та спорту, компетентного, мобільного, готового до зовнішніх і внугрішніх змін, здатного до створення і здійснення стратегій професійного зростання.

Професійна підготовка майбутнього фахівця 3 фізичного виховання та спорту повинна 


\section{ПОНЯТІЙНИЙ АПАРАТ ІТЕРМІНОЛОГІЯСИСТЕМИ ПІДГОТОВКИФАХІВЦІВ З ФІЗИЧНОГО ВИХОВАННЯ ТА СПОРТУ}

організовуватися на принципах пріоритетності розвитку суб' єктності студента, актуалізації його духовного потенціалу, створення умов для плідного творчого самовираження, що безпосередньо пов'язано 3 ефективністю підготовки до професійного саморозвитку. Такий розвиток не можливий без розуміння базового понятійного апарату та термінологічної системи галузі майбутньої профісійної діяльності фахівця. Власне забезпечення умов ефективної фахової комунікації у сфері підготовки фахівців з фізичної культури і спорту актуалізує потребу вивчення та аналізу понятійного апарату та термінології системи підготовки фахівців 3 фізичного виховання іспорту.

Аналіз останніх досліджень і публікацій. Різні аспети розивтку та функціонування термінології професійної підготовки майбутніх фахівців з фізичної культури та спорту заторкували у своїх працях такі науковці як О. Бєлікова, О. Боровська, О. Вацеба, С. Захаріна, І. Іванова, Н. Степанченко, Л. Сущенко, Б. Шиян, І. Янків.

Мета статті полягає у дослідженні та аналізі ключових понять та термінів системи професійної підготовки майбутніх фахівців 3 фізичного виховання та спорту. Досягнення мети передбачає розв'язання таких завдань:

1. Проаналізувати науково-методичну літературу 3 проблеми дослідження.

2. Визначити ключові поняття системи професійної підготовки майбутніх фахівців 3 фізичного виховання та спорту

3. Вибрати та описати базові терміни системи професійної підготовки майбутніх фахівців 3 фізичного виховання та спорту.

Виклад основного матеріалу дослідження. Провівши аналіз літературних джерел з проблеми дослідження, вважаємо за необхідне віднести до ключових наступні поняття “вища освіта", “вища фізкультурна освіта”, “підготовка”, “професійна підготовка", “професійна підготовка майбутніх фахівців з фізичного виховання та спорту”, "професія", “майбутній фахівець 3 фізичної культури”, “майбутній фахівець 3 фізичного виховання та спорту”, “фахівець”, “компетентність” та "професійна компетентність".

У статті 1 Закону України "Про вищу освіту" (2014) вказується, що “вища освіта - це сукупність систематизованих знань, вмінь і практичних навичок, способів мислення, професійних, світоглядних і громадянських якостей, морально-етичних цінностей, інших компетентностей, здобутих у закладі вищої освіти (науковій установі) у відповідній галузі знань за певною кваліфікацією на рівнях вищої освіти, що за складністю є вищими, ніж рівень повної загальної середньої освіти”.

Термін "вища фізкультурна освіта" Н.В. Маковецька трактує як “цілеспрямоване формування знань, вмінь і навичок для засвоєння соціального досвіду досягнення фізичної досконалості" [9, 119].

Розкриємо сутність поняття “підготовка" i “професійна підготовка".

У “Великому тлумачному словнику сучасної української мови” В.Т. Бусела (2005) поняття "підготовка" трактується як “запас знань, навичок, досвід, набутий у процесі навчання та практичної діяльності”.

В “Енциклопедії освіти” під редакцією В.Г. Кременя поняття "професійна підготовка" трактується як сукупність спеціальних знань, вмінь і навичок, якостей, трудового досвіду й норм поведінки, які забезпечують можливість успішної праці за обраною професією [8].

Аналіз психолого-педагогічної літератури свідчить про відсутність єдиного тлумачення поняття “професійна підготовка” (рис. 1).

у “Великому тлумачному словнику сучасної української мови” під редакцією В. Т. Бусела (2005) поняття “професійна підготовка" визначається як “запас знань, навичок, досвід тощо, набутий у процесі навчання, практичної діяльності".

Результатом професійної підготовки є певний рівень сформованості професіоналізму особистості - якості, яку В.Ф. Орлов визначає як таку, що "поєднує в собі компетентність в оцінці ставлення особистості до різних аспектів професійної діяльності, а також цілу структуру соціальних, власне професійних, моральномотиваційних компонентів" і виявляється у комунікативних уміннях (соціальний компонент), компетентності (професійній діяльності), у самовдосконаленні $[11,15]$.

На нашу думку, одним із найоптимальніших $\epsilon$ тлумачення поняття “професійна підготовка майбутніх фахівців з фізичного виховання та спорту”, яке подає Л.П. Сущенко. Вчена визначає поняття "професійна підготовка майбутніх фахівців з фізичного виховання та спорту” як процес, який характеризує технологічно обгрунтовані заходи вищих навчальних закладів країни надавати особистості такого рівня професіоналізму, завдяки якому вона стане конкурентоспроможною на ринках праці, буде самостійно організовувати фізичне виховання різних верств населення регіону й успішно працювати в усіх ланках спортивного руху [14, $128]$. 


\title{
ПОНЯТІЙНИЙ АПАРАТ ІТЕРМІНОЛОГІЯСИСТЕМИ ПІДГОТОВКИ ФАХІВЦІВ З ФІЗИЧНОГО ВИХОВАННЯ ТА СПОРТУ
}

\begin{abstract}
Професійна підготовка - це цілеспрямований процес професійного розвитку фахівця, який забезпечує набуття базових знань, умінь, навичок і практичного досвіду, а також якостей особистості (комунікативних, організаційних тощо), необхідних для здійснення педагогічної діяльності (I. I. Тукач) [15]
\end{abstract}

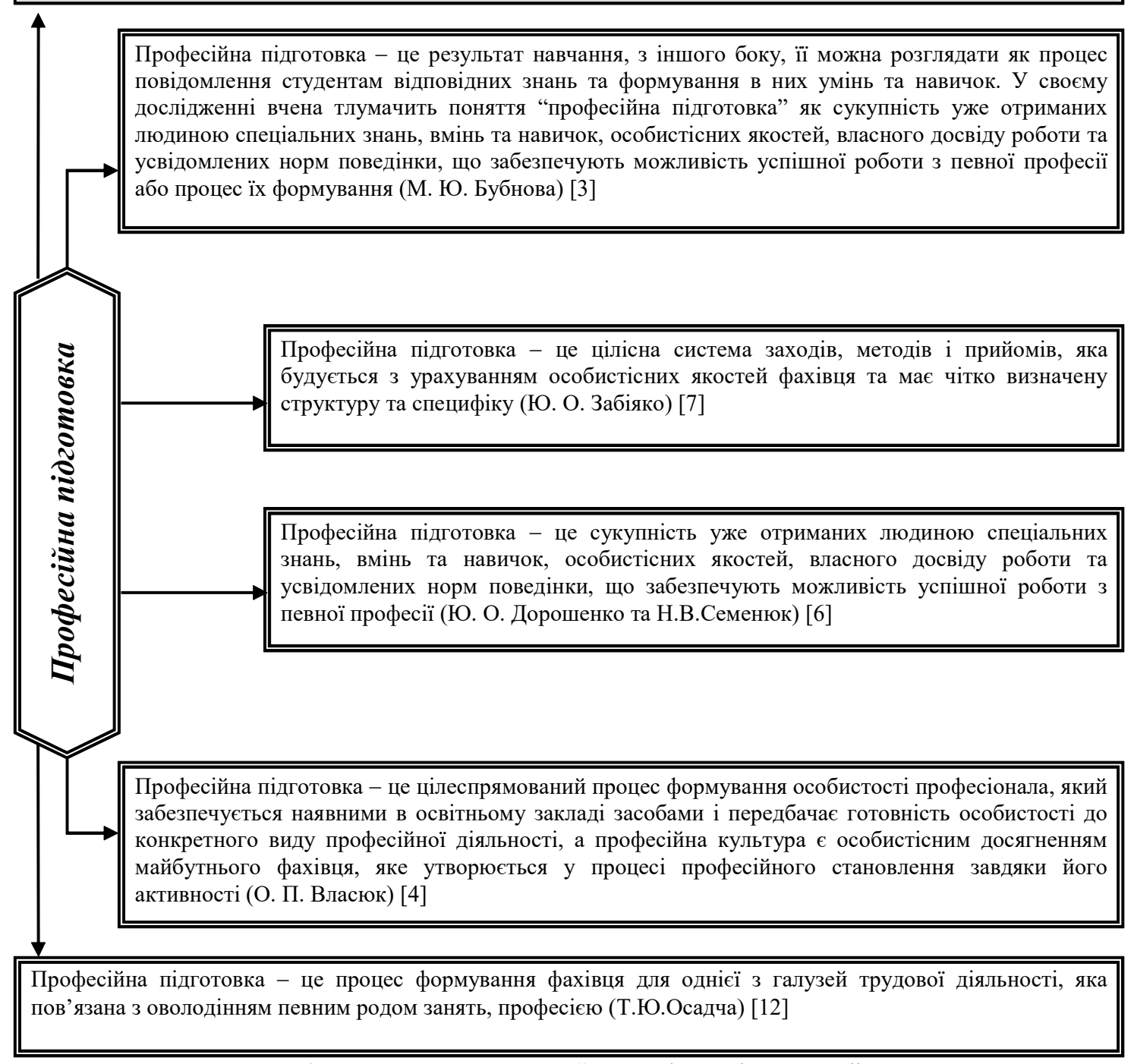

\section{Рис. 1. Визначення поняття "професійна підготовка"}

Наведемо визначення поняття “професія".

Вчені М.С. Герцик та О.М. Вацеба розглядають професію як “своєрідну сукупність умінь, навичок, видів діяльності, особистих захоплень та зацікавлень людини, що слугує джерелом заробітку, сприяє виявленню творчих здібностей і реалізації власних та суспільних устремлінь" $[5,84]$. Ми погоджуємося з думкою науковців і у такому визначенні будемо використовувати поняття “професія” у нашому дослідженні.

Л.П. Сущенко вважає, що “професія визначає місце людини у соціальній структурі та $\epsilon$ джерелом іï духовного i матеріального благополуччя. Професія найчастіше пов'язана 3 освітою, колом інтересів, потребами, вона накладає відбиток на особу, ії світогляд, поведінку тощо” $[14,135]$. Ми поділяємо цю думку вченого.

Професія викладача фізичного виховання, тренера 3 певного виду спорту, на думку H.I. Степанченко, “належить до таких професій, в яких людина, не маючи покликання до цієї діяльності, не може працювати творчо, продуктивно, стати майстром своєї справи. Правдиве покликання визначається тільки в практичній діяльності, що дозволяє рекомендувати її з метою формування професійної спрямованості, а також використовувати в якості критерію професійного відбору” [13, 244].

Наступним етапом нашого дослідження було 


\section{ПОНЯТІЙНИЙ АПАРАТ ІТЕРМІНОЛОГІЯСИСТЕМИ ПІДГОТОВКИФАХІВЦІВ З ФІЗИЧНОГО ВИХОВАННЯ ТА СПОРТУ}

визначення сутності поняття “майбутній фахівець з фізичної культури".

В.В. Мартиненко тлумачить поняття “майбутній фахівець з фізичної культури" як особистість, яка цілеспрямовано здобуває у спеціалізованих вищих навчальних закладах професійну освіту в процесі спеціально організованої навчально-виховної діяльності, спрямованої на підготовкудо подальшої професійної діяльності $[10,56]$. Нам імпонує це визначення поняття “майбутній фахівець 3 фізичної культури".

У дослідженні ми будемо використовувати поняття “майбутній фахівець 3 фізичного виховання та спорту” у тлумаченні, яке подає Л.П. Сущенко. Вчений трактує поняття “майбутній фахівець 3 фізичного виховання та спорту” як “особистість, яка цілеспрямовано здобуває у вищих навчальних закладах спеціальність, що пов'язана з організацією навчально-виховного процесу щодо підтримки певного рівня фізичної культури населення або спрямована на досягнення вищих спортивних результатів на олімпійській, світовій чи регіональній аренах у командному або індивідуальному вимірах" [14, 134].

3'ясуємо сутність поняття “фахівець”. У “Великому тлумачному словнику сучасної української мови” за редакцією В. Бусела (2005) поняття “фахівець” визначається як “той, хто досконало володіє якимось фахом, має високу кваліфікацію, глибокі знання з певної галузі науки, техніки, мистецтва тощо; спеціаліст".

Наступним етапом є з'ясування сутності поняття “компетентність".

У статті 1 Закону України "Про вищу освіту" (2014) зазначено, що “компетентність - це динамічна комбінація знань, вмінь і практичних навичок, способів мислення, професійних, світоглядних і громадянських якостей, моральноетичних цінностей, яка визначає здатність особи успішно здійснювати професійну та подальшу навчальну діяльність і $є$ результатом навчання на певному рівні вищої освіти”.

Під компетентністю фахівця Н.О. Брюханова розуміє властивість професіонала, яка вказує на його спроможність доцільно та ефективно діяти за реальних обставин, тобто реалізовувати компетенції - конкретні групи досвідних надбань стосовно тих чи інших напрямків чи етапів здійснення професійної діяльності [2].

Компетентність, на думку Н.І. Степанченко, можна представити у вигляді взаємодіючих і взаємопроникаючих утворень, структура яких передбачає наявність мотиваційного, особистісного, когнітивного та операційного компонентів $[13,258]$.
У дослідженні ми будемо використовувати поняття “компетентність” у трактуванні яке подає Ю.Д. Бойчук. Вчений тлумачить поняття “компетентність” як “важливий компонент структури особистості, в якому фокусується іï життєвий досвід, здобутий особистістю у процесі отримання освіти, професійної діяльності та шляхом взаємодії зі соціальним середовищем" [1, 196].

В умовах вищої фізкультурної освіти на особливу увагу заслуговує формування професійної компетентності майбутнього фахівця 3 фізичного виховання та спорту.

Професійна компетентність є одним 3 видів ключової компетентності й передбачає володіння професійною діяльністю на достатньо високому рівні, здатність особистості проектувати свій подальший професійний розвиток.

Заслуговує уваги тлумачення поняття “професійна компетентність”, яке подає Ю.Д. Бойчук. На його думку, професійна компетентність $є$ “якістю високопрофесійного працівника, здатного максимально реалізовувати себе в конкретних видах трудової діяльності, здатного адаптуватися до умов, які змінюються разом із ринковим механізмом, що управляє професійною мобільністю, плануванням професійного зростання та професійною самореалізацією” $[1,202]$.

Висновки. Таким чином, охарактеризовано базовий понятійний апарат і термінологія системи професійної підготовки майбутніх фахівців 3 фізичного виховання та спорту. Акцентовано увагу на тому, що професійна підготовка $є$ системою навчання або процесом отримання майбутнім фахівцем спеціальних знань, вмінь та навичок, особистісно-професійних якостей, що забезпечують можливість успішної роботи 3 певної професії. Уточнено сутність понять “формування професійної компетентності майбутніх фахівців 3 фізичного виховання та спорту у закладах вищої освіти" та "майбутні фахівці з фізичного виховання та спорту”. Формування професійної компетентності майбутніх фахівців 3 фізичного виховання та спорту в закладах вищої освіти розглядається як процес оволодіння студентами професійно орієнтованими знаннями, вміннями та навичками, практичним досвідом, а також професійно значущими якостями, достатніми для здійснення ними індивідуального творчого внескуу професію, стимулювання в суспільстві інтересу до результатів своєї роботи, пов'язаної із застосуванням фізичних вправ, природних i гігієнічних чинників упродовж вільного часу 


\section{ПОНЯТІЙНИЙ АПАРАТ ІТЕРМІНОЛОГІЯСИСТЕМИ ПІДГОТОВКИФАХІВЦІВ З ФІЗИЧНОГО ВИХОВАННЯ ТА СПОРТУ}

людини для відновлення, зміцнення та збереження іiі здоров'я.

Майбутні фахівці з фізичного виховання та спорту розглядаються як студенти закладів вищої освіти, які, маючи власні покликання та здібності, спрямовують зусилля на отримання кваліфікації відповідно до певного терміну навчання та освітнього рівня, що дозволить їм навчати інших осіб основним руховим діям з метою досягнення фізичної досконалості.

Перспективи подальших досліджень Основними напрямками подальших досліджень $€$ доповнення вибірки термінологічних одиниць та їх аналіз з метою подальшої стандартизації. Ще одним перспективним напрямом роботи $\epsilon$ укладання галузевого термінологічного словника.

\section{ЛІТЕРАТУРА}

1. Бойчук Ю. Д. Компетентнісний підхід. Наукові підходи до наукових педагогічних досліджень. Харків, 2011. С. 188-216.

2. Брюханова Н. О. Компетентний фахівець цільовий орієнтир сучасної професійної освіти. Професійна освіта: методологія, теорія та технологї, №1. 2015. С.16-25.

3. Бубнова М. Ю. Готовність майбутніх учителів математики до професійної діяльності. Дидактика математики: проблеми і дослідження, Міжнар. зб. наук. робіт. 2010. Донецьк.

4. Власюк О. П. До проблеми професійної підготовки студентів вищих навчальних закладів. 3б. наук. пр. Бердянського держ. пед. ун-ту. Серія: Педагогічні науки. 2011. Бердянськ.

5. Герцик М. С., Вацеба О. М. Вступ до спеціальностей галузі “Фізичне виховання та спорт". Львів, 2002. 232 с.

6. Дорошенко Ю. О., Семенюк Н. В. Сутність теми і зміст педагогічного дослідження. 2009. URL: www.kspu.edu/Downloads/it_conf/4/ DoroshSemen (дата звернення: 15.10.2016).

7. Забіяко Ю. О. Професійна підготовка фахівців фізичної культури та спорту. Фізичне виховання, спорт $i$ культура здоров'я $у$ сучасному суспільстві, №2. 2013. С.16-19.

8. Кремень В. Г. Енциклопедія освіти. Київ, 2008. $1040 \mathrm{c}$.

9. Маковецька Н. В. (2006). Формування фізичної культури і здорового способу життя особистості: теоретичний аспект проблеми. Педагогіка, психологія та медико-біологічні проблеми фізичного виховання $і$ спорту. Наук. моногр., №10. С.117-121.

10. Мартиненко В. В. (2006). Проблеми неперервної професійної підготовки фахівців фізичного виховання і спорту. Педагогіка, психологія та медико-біологічні проблеми фізичного виховання $i$ спорту. Наук. моногр., №3. C. 55-58.

11. Орлов В.Ф. (2003). Професійне становлення вчителів мистецьких дисциплін. Київ.

12. Осадча Т. Ю. Професійна підготовка викладачів фізичного виховання в університетах США./ Автореф. канд. пед. наук. Луганськ, 2005.

13. Степанченко Н. І. Система професійної підготовки майбутніх учителів фізичного виховання у вищих навчальних закладах./Дис. дра пед. наук. Вінниця, 2017.

14. Сущенко Л. П. (2003). Професійна підготовка майбутніх фахівців фізичного виховання та спорту (теоретико-методологічний аспект). Запоріжжя, 2003.

15. Тукач I.I. Професійна підготовка майбутніх фахівців дошкільної освіти до ознайомлення дошкільників з їх правами та обов'язками. Наукові записки Ніжинського держ. ун-ту ім. Миколи Гоголя. Серія: Психолого-педагогічні науки, №6. 2012. C.204-208.

\section{REFERENCES}

1. Boichuk, Yu. D. (2011). Kompetentnisnyi pidkhid [Competency approach]. Scintific approaches to scientific pedagogical researches. Kharkiv, pp. 188-216. [in Ukrainian].

2. Briukhanova, N. O. (2015). Kompetentnyi fakhivets - tsilovyi oriientyr suchasnoi profesiinoi osvity [A competent specialist is the target benchmark of modern professional education]. Professional Education: Methods, Theory and technologies, no.1, pp.16-25. [in Ukrainian].

3. Bubnova, M. Yu. (2010). Hotovnist maibutnikh uchyteliv matematyky do profesiinoi diialnosti [Readiness of future math teachers to the professional activity]. Didactics of Math: Problems and Research. An international collection of scientific works. Donetsk. [in Ukrainian].

4. Vlasiuk, O. P. (2011). Do problemy profesiinoi pidhotovky studentiv vyshchykh navchalnykh zakladiv [To the Problem of Professional Training of Students in Higher Educational Establishmets]. A collection of scientific works of Berdyansk State Pedagogical University. Series: Pedagogical Sciences. Berdiansk. [in Ukrainian].

5. Hertsyk, M. S. \& Vatseba, O. M. (2002). Vstup do spetsialnostei haluzi "Fizychne vykhovannia ta sport" [Introduction to Specialty "Physical Education and Sport"]. Lviv, 232 p. [in Ukrainian].

6. Doroshenko, Yu. O. \& Semeniuk, N. V. (2009). Sutnist temy i zmist pedahohichnoho doslidzhennia [The essence of the topic and the content of pedagogical research]. Available at: www.kspu.edu/ 


\title{
ПОНЯТІЙНИЙ АПАРАТ ІТЕРМІНОЛОГІЯСИСТЕМИ ПІДГОТОВКИФАХІВЦІВ З ФІЗИЧНОГО ВИХОВАННЯ ТА СПОРТУ
}

Downloads/it_conf/4/DoroshSemen (accessed 15 Oct. 2016) [in Ukrainian].

7. Zabiiako, Yu. O. (2013). Profesiina pidhotovka fakhivtsiv fizychnoi kultury ta sportu [Professional training of specialists in physical culture and sports]. Physical Education, Sport and Culture in Modern Society, Vol. 2, pp.16-19. [in Ukrainian].

8. Kremen, V. H. (Ed.). (2008). Entsyklopediia osvity [Encyclopedia of Education]. Kyiv, 1040 p. [in Ukrainian].

9. Makovetska, N. V. (2006). Formuvannia fizychnoi kultury i zdorovoho sposobu zhyttia osobystosti: teoretychnyi aspekt problemy [Development of Physical Culture and Healthy Life Style: theoretical aspect]. Pedagogy, psychology and medical and biological problems of physical education and sports. Science monograph. Vol. 10, pp. 117-121. [in Ukrainian].

10. Martynenko, V. V. (2006). Problemy neperervnoi profesiinoi pidhotovky fakhivtsiv fizychnoho vykhovannia i sportu [Problems of Continious Professional Training of Specialists in Physical Education and Sport]. Pedagogy, psychology and medical and biological problems of physical education and sports. Science monograph. No.3, pp.55-58. [in Ukrainian].

11. Orlov, V. F. (2003). Profesiine stanovlennia vchyteliv mystetskykh dystsyplin [Professional
Development of Art Subjects Teachers]. Kyiv. [in Ukrainian].

12. Osadcha, T. Yu. (2005). Profesiina pidhotovka vykladachiv fizychnoho vykhovannia v universytetakh SShA [Professional Training of Physical Education Teachers in the USA Universities]. Candidate's thesis. Luhansk. [in Ukrainian].

13. Stepanchenko, N. I. (2017). Systema profesiinoi pidhotovkymaibutnikh uchyteliv fizychnoho vykhovannia $\mathrm{u}$ vyshchykh navchalnykh zakladakh [System of Professional Training of Future Physical Education Teacher in Higher Educational Establishmets]. Doctor's thesis. Vinnytsia. [in Ukrainian].

14. Sushchenko, L. P. (2003). Profesiina pidhotovka maibutnikh fakhivtsiv fizychnoho vykhovannia ta sportu: teoretyko-metodolohichnyi aspekt [Professional Training of Future Physical Education and Sport Specialists: theory and methodology]. Zaporizhzhia. [in Ukrainian].

15. Tukach, I.I. (2012). Profesiina pidhotovka maibutnikh fakhivtsiv doshkilnoi osvity do oznaiomlennia doshkilnykiv z yikh pravamy ta oboviazkamy [Professional training of future preschool education specialists to the familiarize preschoolers with their rights and responsibilities]. Scientific notes of the Nizhyn Mykola Hohol State University. Series: Psychological and pedagogical sciences. No.6, pp.204-208. [in Ukrainian].

\section{G58089

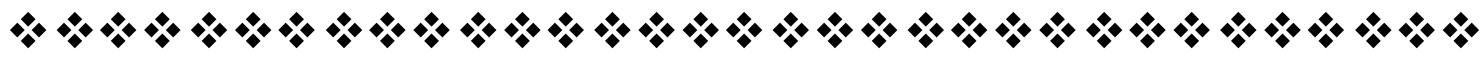

"Фавай настанови лише тим, хто шуқає знання, визнавши своє невігластво. Dопомагай лише тому, хто не вміє чітко висловлювати свої найпотаємніші думки. Навчай лише того, хто здатен, дізнавщись про один кут квадрата, уявити собі решту три".

Конфучиій

давньокитайський фбілософб

\begin{abstract}
“Знання неоиінене багатство, яқого маєи набути в роқи отрочтва, ранньої юності”.

Василь Сухомлинський уқрайнський педагог, публіиист, письменник
\end{abstract}

“Розум зводиться не тільқи до знань, але й в умінні пристосовувати знання в справі..."

Apicmomess

давнъогреиький боілособ

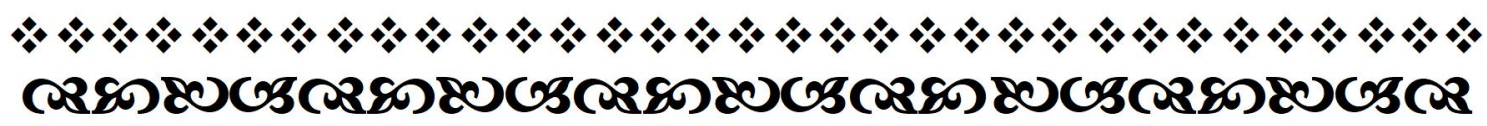

